\title{
PEMANFAATAN MEDIA SURAT KABAR SEBAGAI MATERIBAHASA INDONESIA DAN INTEGRASI KARAKTER
}

\author{
Muhammad Zakia Firdaus \\ Pendidikan Bahasa Indonesia, Universitas Billfath \\ INFO ARTIKEL \\ Diterima:3-02-2020 \\ Disetujui:15-02-2020 \\ Kata Kunci: \\ Media surat kabar, \\ karakter

\begin{abstract}
Abstrak: Penelitian ini bertujuan mendeskripsikan 1) pemanfaatan wacana Mimbar Jumat surat kabar Solopos sebagai materi pelajaran Bahasa Indonesia 2) mengetahui integrasi karakter wacana Mimbar Jumat surat kabar Solopos sebagai materi pelajaran Bahasa Indonesia. Jenis penelitian ini adalah kualitatif deskriptif. Hasil penelitian ini menyatakan media surat kabar dapat digunakan sebagai media pembelajaran dan terdapat nilai karaktek.
\end{abstract}

\begin{abstract}
The purpose of this study to describe 1) Use of discours Mimbar Jumat Solopos newspaper as material in Indonesian Language lesson 2) Know the character integartion discours Mimbar Jumat Solopos newspaper as material in Indonesian Language lesson. This type of research descriptive qualitative. The results of study show that wacana Mimbar Jumat can be used a resource materialsand there is charakter value
\end{abstract}

Alamat Korespondensi:

Pendidikan Bahasa Indonesia

Universitas Billfath

Komplek PP Al-Fattah Siman, Sekaran, Lamongan, Jawa Timur, Indonesia mzakiafirdaus@g.mail.com

Perkembangan zaman yang begitu cepat mempengaruhi semua lini kehidupan. Dunia pendidikan pun tidak luput dari perkembangan zaman tersebut. Salah satu indikator yang dapat diambil adalah adanya perubahan perkembangan kurikulum dan perkembangan materi pelajaran. Khususnya pelajaran bahasa Indonesia, dalam perkembangan Kurikulum 2013 yaitu adanya materi yang berbasis teks bacaan atau wacana. Hal tersebut tentunya untuk meningkatkan kegiatan literasi di Indonesia. Selain itu, hal yang menjadi inti Kurikulum 2013 mengenai pendidikan berkarakter.

Jika kita lihat, materi-materi yang ada di pelajaran Bahasa Indonesia dalam kurikulum 2013 khususnya untuk tingkat SMA/MA berbasis teks. Silabus Kemendikbud (2016) menyatakan sebagai berikut. Kelas X; Laporan Hasil Observasi, Teks Eksposisi, Anekdot, Hikayat, Ikhtisar Buku, Teks Negosiasi, Debat, Cerita Ulang (Biografi), Puis, Resensi Buku. Kelas XI; Teks Prosedur, Jenis Kalimat, Teks Eksplanasi, Struktur Teks, Ceramah, Pengayaan Non Fiksi, Cerpen, Proposal, Karya Ilmiah, Resensi, Drama, Novel. Kelas XII; Surat Lamaran, Novel Sejarah, Teks Editorial, Novel, Unsur Kebahasaan, Artikel, Fakta dan Opini, Kritik, Drama. 
KARANGAN: Jurnal Kependidikan, Pembelajaran, dan Pengembangan, Vol 02, No 01, Bln Feb, Tahun 2020, Ha 42 - 45

Materi-materi tersebut tentunya menuntut murid untuk senantiasa membaca dan mengembangkan daya membacanya. Teks-teks bahasa dan sastra tersebut tentunya diambil dari berbagai macam sumber bacaan. Misalkan dalam teks eksplanasi, teks yang disajikan adalah teks yang berkaitan dengan fenomena alam dan sosial. Maka murid dalam pelajaran Bahasa Indonesia selain mengetahui ilmu Bahasa Indonesia juga mengetahui disiplin ilmu yang lain. Tentunya dalam Bahasa Indonesia ranahnya adalah analisis struktur teks, kaidah kebahsaan teks, dan membuat teks serupa.

Seorang guru tentunya dituntut untuk senantiasa kratif dalam mengajar. Selain itu, pemanfaatan media yang ada juga harus dioptimalkan. Anitah (dalam Sufanti, 2012) Media adalah setiap orang, bahan, alat, atau peristiwa yang dapat menciptakan kondisi yang memungkinkan pebelajar untuk menerima pengetahuan, keterampilan, dan sikap. Salah satu media yang dapat digunakan adalah media surat kabar. Surat kabar cetak saat ini masih menjadi media yang bermanfaat. Di dalam surat kabar Solopos wacana Mimbar Jumat edisi Maret-April 2014 dapat dijadikan materi pembelajaran dan pembentuk karakter. Chaer (1994:267) menyatakan wacana adalah suatu bahasa yang lengkap sehingga dalam hierarki gramatikal merupakan suatu gramatikal tertinggi atau terbesar. Wacana dikatakan lengkap karena di dalamnya terdapat konsep gagasan, pikiran dan ide yang utuh yang bisa dihadapi oleh pembaca (dalam wacana tulis) atau oleh pendengar (dalam wacana lisan) karena wacana dibentuk dari kalimat yang memenuhi pernyataan gramatikal dan persyaratan wacana lainya (kohesi dan koherensi).

Nugrahani (2012) menyatakan pembelajaran karakter dapat diperoleh melalui materi kebahasaan dan kesusastraan. Terdapat Sembilan pilar nilai karakter (1) cinta kepada Tuhan dan alam semesta beserta isinya, (2) tanggung jawab, kedisiplinan, dan kemandirian, (3) kejujuran, (4)hormat dan sopan santun, (5) kasih sayang, kepedulian, dan kerja sama, (6) percaya diri, kreatif, kerja keras dan pantang mennyerah, (7) keadilan dan kepemimpinan, (8) baik dan rendah hati, (9) tolenransi, cinta damai, dan persatuan.

Selain itu, Rohman, (2012) yang diperlukan sekarang adalah kurikulum berkarakter; dalam arti kurikulum itu sendiri memiliki karakter, dan sekaligus diorientasikan bagi pembentukan karakter peserta didik. Pemanfaatan media pembelajaran dari berbagai hal sangat mungkin dilakukan untuk pembentukan karakter.

\section{METODE}

Dalam penelitian ini menggunakan penelitian kualitattif deskriptif. Sugiyono (2017) penelitian kualitatif adalah metode penelitian yang berlandaskan pada filsafat postpositivisme, digunakan untuk meneliti pada kondisi obyek yang alamiah, (sebagai lawannya adalah eksperimen) dimana peneliti adalah sebagai instrument kunci, teknik pengumpulan data dilakukan secara triangulasi (gabungan), analisis data bersifat induktif/kualitatif, dan hasil penelitian lebih menekankan pada makna dari pada generalisasi.

Data dalam penelitian ini adalah wacana Mimbar Jumat edisi Maret-April 2014. Terdapat tujuh judul wacana sebagai berikut. "Teladan Imam", "Didoakan Malaikat", "Bhineka Tunggal Ika", "Badai Pasti Berlalu", "Membentuk Karakter ", "Ketidakjujuran Publik", "Mematuhi Pemimpin". Data tersebut kemudian dikelompokkan sesuai dengan teks yang ada dalam Kurikulum 2013 pelajaran Bahasa Indonesia tingkat SMA/MA sederajat.

Langkah penelitian ini diawali dengan mencari dan mencatat data. Kemudian setelah data didapatkan, data terebut dideskripsikan dan dikelompokkan 
seseuai kebutuhan penelitian. Terakhir adalah penyajian data yang ditampilkan dalam bentuk uraian.

\section{HASIL DAN PEMBAHASAN}

\section{Wacana Mimbar Jumat Solopos Sebagai Materi Bahasa Indonesia}

Pemanfaatan media surat kabar dalam pelajaran Bahasa Indonesia secara efektif dapat dilakukan sesuai kebutuhan. Di dalam surat kabar terdapat berbagai macam kolom yang dapat dipilih dan dipilah sesuai kebutuhan materi yang ada. Dalam penelitian ini, wacana Mimbar Jumat Solopos sesuai dengan meteri teks anekdot, eksplanasi, dan eksposisi.

Tabel 1. Kesesuaian Wacana Mimbar Jumat dengan Materi Bahasa Indonesia

\begin{tabular}{cccc}
\hline NO. & JUDUL & PENULIS & JENIS TEKS \\
\hline 1 & "Teladan Imam" & Muhsin Al Jufri & Anekdot \\
\hline 2 & "Didoakan Malaikat" & Muhsin Al Jufri & Ekposisi \\
\hline 3 & "Bhineka Tunggal Ika" & Ahmad Sukina & Ekposisi \\
\hline 4 & "Badai Pasti Berlalu" & Ahmad Sukina & Eksplanasi \\
\hline 5 & "Membentuk Karakter & Mutohharun Jihan & Ekposisi \\
\hline 6 & $\begin{array}{c}\text { "Ketidakjujuran } \\
\text { Publik" }\end{array}$ & Mutohharun Jihan & Ekposisi \\
\hline 7 & "Mematuhi Pemimpin" & M. Dian Nafi & Ekposisi \\
\hline
\end{tabular}

Genre teks yang terdapat dalam Wacana Mimbar Jumat Solopos adalah teks anekdot, teks eksplanasi, dan teks eksposisi. Teks anekdot merupaka teks yang didalamnya terdapat pesan atau nasihat yang disampaikan dengan adanya unsur humor. Teks eksplanasi merupakan teks yang didalamnya membahas mengenai fenomena alam dan fenomena sosial. Sedangkan teks ekposisi adalah teks yang didalamnya terdapat uraian menjelaskan sesuatu.

Dapat diketahui bahwa teks yang terdapat dalam surat kabar masih bermafaat dan masih relevan dengan kebutuhan serta pemenuhan perkembangan dunia pendidikan zaman sekarang. Guru secara berkesinambungan dapat mengarahkan murid untuk memanfaatkan media yang ada. Media surat kabar juga menjadi salah satu solusi sebagai media nondaring di Indonesia, terkhusus bagi wilayah Indonesia belum tersentuh oleh media berbasis daring.

\section{Wacana Mimbar Jumat Solopos Sebagai Pembentuk Karakter}

Wacana adanya perkembangan Kurikulum 2013 adalah pembetukan karakter positif murid. Unsur-unsur pendidikan haruslah menyambut baik program pemerintah tersebut. Guru sebagai pelaksana langsung kegiatan pembelajaran secara kreatif dapat menggunakan berbagai sumber dan media belajar yang ada. Dalam penelitian ini menyampaikan adanya nilai karakter yang dapat digunakan dalam pembelajaran Bahasa Indonesia tingkat SMA/MA sederajat. 
KARANGAN: Jurnal Kependidikan, Pembelajaran, dan Pengembangan, Vol 02, No 01, Bln Feb, Tahun 2020, Ha 42 - 45

Tabel 2. Wacana Mimbar Jumat Solopos Sebagai Pembentuk Karakter

\begin{tabular}{cccc}
\hline NO. & JUDUL & PENULIS & KAREKTER \\
\hline 1 & "Teladan Imam" & Muhsin Al Jufri & Peduli \\
\hline 2 & "Didoakan Malaikat" & Muhsin Al Jufri & Peduli \\
\hline 3 & "Bhineka Tunggal Ika" & Ahmad Sukina & Toleransi \\
\hline 4 & "Badai Pasti Berlalu" & Ahmad Sukina & Sabar \\
\hline 5 & "Membentuk Karakter & Mutohharun Jihan & Peduli \\
\hline 6 & $\begin{array}{c}\text { "Ketidakjujuran } \\
\text { Publik" }\end{array}$ & Mutohharun Jihan & Kejujuran \\
\hline 7 & "Mematuhi Pemimpin" & M. Dian Nafi & Kapatuhan \\
\hline
\end{tabular}

Pemanfaatan media surat kabar sebagai pembentuk karakter dapat dilakukan dengan mudah. Guru dapat mengarahkan murid untuk membaca, menganalisis isi, kemudian menuliskan pesan yang ada dalam wacana tersebut. Selanjutnya, guru mengaitkan antara genre teks dan nilai karakter yang ada di dalam wacana tersebut dalam pembelajaran Bahasa Indonesia.

\section{SIMPULAN}

Pemanfaatan media pembelajaran yang ada disekitar merupakan bentuk kreativitas guru. Media cetak surat kabar juga menjadi solusi bagi daerah yang belum tersentuh atau kesulitas mengenai media berbasis daring. Pengintegrasian antara materi, media pembelajaran, dan pembentukkan karakter dapat dilakukan secara bersamaan.

Hal tersebut merupakan upaya agar tujuan pendidikan nasional tercapai. Melaksanakan pembelajaran secara optimal dengan menggunakan media yang ada menjadi salah satu syarat tercapainya tujuan pendidikan di Indonesia. Media surat kabar masih bermanfaat dan relevan untuk membantu mewujudkan tujuan tersebut.

\section{DAFTAR RUJUKAN}

Chaer, Abdul. 2007. Linguistik Umum. Jakarta: Rindu Cipta.

Kementrian Pendidikan dan Kebudayaan. (2016). Silabus Mata Pelajaran Sekolah Menengah Atas/Madrasah Aliyah/Sekolah Menengah Kejuruan/Madrasah Aliyah Kejuruan (SMA/MA/SMK/MAK). Jakarta: Kementrian Pendidikan dan Kebudayaan.

Nugrahani, Farida. (2012). Reaktualisasi Tembang Dolanan Jawa dalam Rangka Pembentukan Karakter Bangsa (Kajian Semiotik). Kajian Linguistik dan Sastra, Vol. 24, No.1, Juni 2012: 58-68.

Rohman, Muhammad. (2012). Pendidikan Berkarakter. Jakarta: Prestasi Pustaka Publisher.

Sufanti, Main. (2012). Strategi Pengajaran Bahasa dan Sastra Indonesia. Surakarta: Yuma Pustaka. 